\title{
Production of fish seasoning powder from snakehead meat (Channa striata) by applying Alcalase and Flavourzyme enzyme mixture
}

Thu T. M. Truong*, \& Thuy T. M. Le

College of Aquaculture and Fisheries, Can Tho University, Can Tho, Vietnam

ARTICLE INFO
Research Paper
Received: March 03, 2020
Revised: April 10, 2020
Accepted: April 21, 2020
Keywords
Alcalase
Fish hydrolysate solution
Fish seasoning powder
Flavourzyme
Snakehead fish
*Corresponding author
Truong Thi Mong Thu
Email: ttmthu@ctu.edu.vn

\begin{abstract}
Fish hydrolysate was produced from snakehead meat by applying an enzyme mixture consisting of Alcalase and Flavourzyme with a ratio of 1:3; hydrolysis temperature $55^{\circ} \mathrm{C} ; \mathrm{pH} 6.5-6.9$. The results showed that the ratio of enzyme mixture to fish meat of $0,2 \%$ and hydrolysis time of $26 \mathrm{~h}$ were the optimal hydrolysis conditions. Fish hydrolysate had highest peptide content $(26,4 \mathrm{~g} / \mathrm{L})$ and nitrogen amino acid content $(10,6 \mathrm{~g} / \mathrm{L})$, and lowest nitrogen ammonia content $(0,257 \mathrm{~g} / \mathrm{L})$. Sensory score, protein content, recovery yield and moisture content of fish seasoning powder were 18,$9 ; 17,1 \% ; 42,5 \%$ and $4,88 \%$, respectively by mixing radish solution and fish hydrolysate at the ratio of radish solution to fish hydrolysate of $25 \%: 40 \%$ and drying at $60^{\circ} \mathrm{C}$ for $72 \mathrm{~h}$. The product still remained good sensory quality. The moisture content and total aerobic bacteria of product were at acceptable level after 4 weeks stored at ambient temperature.
\end{abstract}

Cited as: Truong, T. T. M., \& Le, T. T. M. (2020). Production of fish seasoning powder from snakehead meat (Channa striata) by applying Alcalase and Flavourzyme enzyme mixture. The Journal of Agriculture and Development 19(2), 43-49. 


\title{
Sản xuất bột nêm từ thịt cá lóc (Channa striata) bằng phương pháp ứng dụng hỗn hợp enzyme Alcalase và Flavourzyme
}

\author{
Trương Thị Mộng Thu* \& Lê Thị Minh Thủy
}

Khoa Thủy Sản, Trường Đại học Cần Thơ, Cần Thơ

\section{THÔNG TIN BÀI BÁO}

Bài báo khoa học

Ngày nhận: 03/03/2020

Ngày chỉnh sửa: 10/04/2020

Ngày chấp nhận: 21/04/2020

\section{Từ khóa}

Alcalase

Bột nêm

Cá lóc

Dịch đạm

Flavourzyme

\section{*Tác giả liên hệ}

Trương Thị Mộng Thu

Email: ttmthu@ctu.edu.vn

\section{TÓM TẮT}

Dịch đạm thủy phân đã được sản xuất từ thịt cá lóc bằng phương pháp ứng dụng hỗn hợp enzyme Alcalase và Flavourzyme, tỷ lệ Alcalase và Flavourzyme là 1:3, ở nhiệt độ thủy phân $55^{\circ} \mathrm{C}, \mathrm{pH} 6,5-6,9$. Kết quả nghiên cứu cho thấy điều kiện thủy phân thích hợp là tỷ lệ hỗn hợp enzyme so với thịt cá và thời gian thủy phân là $0,2 \%: 26$ giờ. Dịch thủy phân có hàm lượng peptide $(26,4 \mathrm{~g} / \mathrm{L})$ và hàm lượng nitơ axit amin $(10,6$ $\mathrm{g} / \mathrm{L})$ cao nhất, hàm lượng nitơ amoniac thấp nhất $(0,257 \mathrm{~g} / \mathrm{L})$. Điểm cảm quan, hàm lượng protein, hiệu suất thu hồi và độ ẩm của bột nêm thành phẩm lần lượt là 18,$9 ; 17,1 \% ; 42,5 \%$ và $4,88 \%$, tương ứng khi phối trộn theo tỷ lệ dịch củ cải trắng và dịch đạm là $25 \%: 40 \%$ và sấy ở $60^{\circ} \mathrm{C}$ trong 72 giờ. Sản phẩm vẫn đảm bảo chất lượng cảm quan tốt, độ ẩm và vi sinh nằm trong giới hạn cho phép sau 4 tuần bảo quản ở nhiệt độ phòng.

\section{1. Đặt Vấn Đề}

Cá lóc (Channa striata) được nuôi phổ biến ở Đồng Bằng sông Cửu Long (ĐBSCL) bởi chất lượng thịt thơm ngon, giá thành hợp lý và là đối tượng nuôi nhiều triển vọng. Sản lượng nuôi cá lóc ở ĐBSCL tăng từ 5.300 tấn năm 2004 lên 40.000 tấn năm 2010 (Le \& ctv., 2014). Tuy nhiên, cá lóc chủ yếu được chế biến dưới dạng sản phẩm khô và mắm, chưa đem lại hiệu quả kinh tế cao (Bui \& ctv., 2014). Vấn đề nghiên cứu nhằm đa dạng hóa sản phẩm từ cá lóc, tiêu thụ và mang lại thu nhập cao cho người nuôi là rất cần thiết.

Do đó, việc sử dụng enzyme thương mại để thủy phân cá lóc nhằm nâng cao hiệu quả kinh tế và đa dạng hóa các sản phẩm từ loài cá này đã và đang được coi là một trong những phương pháp hiệu quả nhất. Các enzyme thủy phân được sử dụng phổ biến trong các nghiên cứu thủy phân bằng enzyme là Alcalase, Flavourzyme, Neutrase, Protamex và Kojizyme (Nguyen \& ctv., 2011).
Alcalase có hoạt tính endopeptidase có nguồn gốc từ vi khuẩn Bacillus licheniformis (Liaset \& ctv., 2002), endopeptidase thủy phân liên kêt peptide chủ yếu tại các nhóm - $\mathrm{COOH}$ ky nước bên trong phân tử protein (Chiang \& ctv., 2019). Flavourzyme có cả hoạt tính endopeptidase và exopeptidase nhưng chủ yếu là exopeptidase, có nguồn gốc từ Aspergillus oryzae (Kamnerdpetch \& ctv., 2007). Nhờ vào hoạt tính exopeptidase của Flavourzyme, thủy phân từ đầu-C hoặc đầu$\mathrm{N}$ của các amino acid ky nước cuối cùng của phân tử protein dẫn đến giảm vị đắng của dịch đạm thu được (Chiang \& ctv., 2019).

Bên cạnh đó, bột nêm sản xuất từ nguyên liệu thủy sản là sản phẩm khá mới ở nước ta hiện nay. Gần đây, Pham (2013) đã ứng dụng hỗn hợp enzyme Alcalase và Flavourzyme để thủy phân đầu tôm thẻ chân trắng. Do \& Nguyen (2017) cũng đã nghiên cứu ứng dụng hỗn hợp Alcalase và Flavourzyme để thủy phân cá nục gai (Decapterus russelli) thu hồi dịch đạm thủy phân. Một số tác 
giả khác cũng đã nghiên cứu ứng dụng enzyme để thủy phân nguyên liệu thủy sản như cá trích của Tran \& Do (2016) và phụ phẩm cá hồi của Tran \& ctv. (2017). Tuy nhiên, chưa có nghiên cứu ứng dụng hỗn hợp enzyme Alcalase và Flavourzyme thủy phân thịt cá lóc để sản xuất sản phẩm bột nêm. Vì vậy, đề tài "Sản xuất bột nêm từ thịt cá lóc (Channa striata) bằng phương pháp ứng dụng hỗn hợp enzyme Alcalase và Flavourzyme" được thực hiện để sản xuất sản phẩm bột nêm từ thịt cá lóc có giá trị dinh dưỡng cao, góp phần đa dạng hóa sản phẩm bột nêm và nâng cao giá trị nguyên liệu cá lóc.

\section{Vật Liệu và Phương Pháp Nghiên Cứu}

\subsection{Vật liệu nghiên cứu}

Cá lóc được mua từ chợ Tân An, phường Tân An, quận Ninh Kiều, thành phố Cần Thơ. Với trọng lượng 500-600 g/con, cá được fillet tách thịt, rửa sạch, cắt nhỏ, xay thô 10 giây và tiến hành thí nghiệm. Alcalase và Flavourzyme là các enzyme protease được sản xuất bởi Công ty Novozyme của Đan Mạch. Enzyme Alcalase có hoạt độ là 2,4 $\mathrm{AU}$ (Anson Units)/g, điều kiện hoạt động thích hợp là nhiệt độ $55-70^{\circ} \mathrm{C}, \mathrm{pH}=$ 6,5 - 8,5. Enzyme Flavourzyme có hoạt độ là 500 LAPU (Leucine Aminopeptidase Units) $/ \mathrm{g}$, điều kiện hoạt động thích hợp là $50-55^{\circ} \mathrm{C}, \mathrm{pH}=5,0$ $-7,0$.

\subsection{Phương pháp bố trí thí nghiệm}

2.2.1. Thí nghiệm 1: Ảnh hưởng của tỷ lệ hỗn hợp enzyme Alcalase và Flavourzyme so với thịt cá và thời gian thủy phân đến chất lượng dịch đạm

Thịt cá lóc đã được xử lý theo mục 2.1. được thủy phân theo phương pháp của Do \& Nguyen (2017) với một vài điều chỉnh cho phù hợp với điều kiện thí nghiệm. Thí nghiệm được thực hiện với 1 yếu tố (ảnh hưởng của tỷ lệ hỗn hợp enzyme Alcalase và Flavourzyme so với thịt cá và thời gian thủy phân là $0,2 \%$ : 20 giờ; $0,3 \%$ : 20 giờ; $0,4 \%$ : 20 giờ; $0,2 \%$ : 26 giờ; $0,3 \%: 26$ giờ và $0,4 \%$ : 26 giờ), 3 lần lặp lại, khối lượng mỗi mẫu là $30 \mathrm{~g}$ thịt cá. Tỷ lệ thịt cá: nước: ethanol $35^{\circ}$ là $1: 0,8$ : 0,2. Tiến hành thủy phân ở điều kiện $\mathrm{pH}$ 6,5 - 6,9, nhiệt độ $55^{\circ} \mathrm{C}$, tỷ lệ Alcalase và Flavourzyme là 1:3. Sau quá trình thủy phân, bất hoạt enzyme ở nhiệt độ $95^{\circ} \mathrm{C}$ trong 15 phút. Tiến hành lọc mẫu để loại bỏ phần cặn, thu phần dịch đạm. Xác định hàm lượng peptide, nitơ axit amin và nitơ amoniac trên phần dịch đạm nhằm tìm được tỷ lệ hỗn hợp enzyme Alcalase và Flavourzyme so với thịt cá và thời gian thủy phân thích hợp nhất.

\subsubsection{Thí nghiệm 2: Nghiên cứu ảnh hưởng của tỷ lệ dịch củ cải trắng phối trộn với dịch đạm đến chất lượng bột nêm}

Thí nghiệm được thực hiện với 1 yếu tố (tỷ lệ dịch củ cải trắng: dịch đạm lần lượt là $20 \%: 45 \%$, 25\%: 40\%, 30\%: 35\%,35\%: 30\%, với 3 lần lặp lại. Khối lượng mỗi mẫu là $30 \mathrm{~g}$ hỗn hợp (gồm $65 \%$ dịch củ cải trắng: dịch đạm và $35 \%$ phụ gia, gia vị). Củ cải trắng, rửa sạch, cắt nhỏ và xay nhuyễn, lọc bằng vải lọc để loại bã. Phối trộn dịch củ cải trắng với dịch đạm (thu được từ kết quả thí nghiệm 1) theo các tỷ lệ bố trí thí nghiệm. Vởi tỷ lệ phụ gia, gia vị cố định gồm $6 \%$ muối, $15 \%$ bột bắp, $1 \%$ tiêu, $3 \%$ củ hành, $10 \%$ maltodextrin. Trộn thật kỹ, trãi đều lên khay và sấy ở $60^{\circ} \mathrm{C}$ trong 72 giờ bằng thiết bị sấy đối lưu tự nhiên $\mathrm{ED}$ 400 Binder (Đức) đến độ ẩm $<3 \%$ và cảm quan sản phẩm đạt theo TCVN 7396 : 2004 (2004). Phân tích cảm quan, độ ẩm, protein tổng số và tính hiệu suất thu hồi của sản phẩm bột nêm nhằm tìm được tỷ lệ dịch củ cải trắng: dịch đạm thích hợp.

\subsubsection{Thí nghiệm 3: Nghiên cứu ảnh hưởng của thời gian bảo quản ở nhiệt độ phòng đến chất lượng bột nêm thành phẩm}

Bột nêm thu được từ thí nghiệm 2 được xay mịn cho vào túi $\mathrm{PA}$ (30 g/túi) hút chân không, tiến hành bảo quản ở nhiệt độ phòng $\left(24-34^{\circ} \mathrm{C}\right)$ trong 4 tuần $(0,1,2,3$ và 4 tuần). Thí nghiệm được thực hiện 3 lần lặp lại, khối lượng mỗi mẫu là $30 \mathrm{~g}$ bột nêm. Phân tích cảm quan, tổng số vi khuẩn hiếu khí và độ ẩm của sản phẩm bột nêm mỗi tuần để tìm được thời gian bảo quản thích hợp nhất theo TCVN 7396 : 2004 (2004).

\subsection{Phương pháp phân tích}

Thành phần hóa học của nguyên liệu thịt cá lóc và bột nêm thành phẩm được xác định theo Latimer (2016), cụ thể hàm lượng ẩm bằng phương pháp sấy, lipid thô bằng phương pháp Soxhlet, khoáng bằng phương pháp nung, protein tổng số bằng phương pháp Kjeldahl.

Phân tích cảm quan bằng phương pháp cho điểm bởi hội đồng cảm quan gồm 13 thành viên. Cảm quan viên được yêu cầu đánh giá các chỉ 
tiêu như màu sắc, mùi, vị và trạng thái được mô tả trong bảng mô tả sản phẩm được xây dựng theo TCVN 3215-79 (1979). Xác định tổng số vi khuẩn hiếu khí theo phương pháp đổ đĩa, đếm khuẩn lạc trên môi trường thạch sau khi ủ hiếu khí ở nhiệt độ $30 \pm 1^{\circ} \mathrm{C}$ trong thời gian từ 48 đến 72 giờ theo TCVN 5165 : 1990 (1990). Xác định hàm lượng nitơ axit amin theo TCVN 3708 - 90 (1990). Xác định hàm lượng nitơ amoniac theo TCVN 3706 - 90 (1990).

Xác định hiệu suất thu hồi $\mathrm{H}=\frac{\mathrm{Y}}{\mathrm{X}} \mathrm{x} 100 \%$. Trong đó: $\mathrm{Y}(\mathrm{g})$ là khối lượng bột nêm thu được sau sấy; X (g) là khối lượng mẫu đem thủy phân.

Hàm lượng peptide: Chuẩn bị mẫu theo phương pháp của Barrett \& Heath (1977) trích dẫn của Hultmann \& ctv., (2012) với một vài điều chỉnh nhỏ. Cho $1,2 \mathrm{~mL}$ dung dịch đệm có $\mathrm{pH} 5,5$ vào ống nghiệm, cho tiếp $0,8 \mathrm{~mL}$ dịch đạm (mẫu sau khi lọc), lắc đều, cho thêm $2 \mathrm{~mL}$ trichloroacetic acid (TCA $5 \%$ ), lắc đều để yên 30 phút, sau đó lọc bỏ kết tủa thu phần dịch lọc. Hàm lượng peptide có trong dịch lọc được đo theo phương pháp của Lowry \& ctv., (1951).

\subsection{Phương pháp xử lý số liệu}

Số liệu thu thập được tính trung bình, độ lệch chuẩn sử dụng chương trình Microsoft Excel 2010. Sự khác biệt của các yếu tố giữa các nghiệm thức được phân tích bằng ANOVA một yếu tố với mức ý nghĩa $95 \%$ và phép thử Duncan $(P<0,05)$ bằng chương trình SPSS 18.0.

\section{Kết Quả và Thảo Luận}

\subsection{Thành phần hóa học của thịt cá lóc}

Kết quả phân tích thành phần hóa học như độ ẩm, protein, khoáng và lipid của thịt cá lóc được thể hiện trong Bảng 1.

Từ Bảng 1 cho thấy thịt cá lóc có hàm lượng protein tương đối cao $(16,9 \%)$ và hàm lượng lipid chiếm tỷ lệ thấp $(1,60 \%)$ rất thích hợp cho sản xuất dịch đạm thủy phân (Do \& Nguyen, 2017).

\section{2. Ảnh hưởng của tỷ lệ hỗn hợp enzyme so với thịt cá và thời gian thủy phân đến hàm lượng peptide, nitơ axit amin và nitơ amo- niac của dịch đạm}

Trong các thông số sinh hóa của quá trình thủy phân thì hàm lượng peptide và hàm lượng nitơ axit amin là những thông số quan trọng nhất vì nó trực tiếp ảnh hưởng đến chiều dài peptide, giá trị dinh dưỡng và các tính chất cảm quan của sản phẩm thủy phân (Tran \& Do, 2016). Hàm lượng peptide, nitơ axit amin và nitơ amoniac của dịch đạm được thể hiện trong Bảng 2.

Từ Bảng 2 cho thấy thời gian thủy phân và tỷ lệ hỗn hợp enzyme có sự ảnh hưởng đồng thời đến quá trình thủy phân $(P<0,05)$. Ở tỷ lệ hỗn hợp enzyme thấp $0,2 \%$ và thời gian thủy phân ngắn 20 giờ thì hàm lượng nitơ axit amin cao nhất (11,4 $\mathrm{g} / \mathrm{L})$, hàm lượng nitơ amoniac thấp nhất $(0,258$ $\mathrm{g} / \mathrm{L})$, nhưng hàm lượng peptide thấp $(25,4 \mathrm{~g} / \mathrm{L})$. Tuy nhiên, khi kéo dài thời gian thủy phân 26 giờ ở cùng tỷ lệ enzyme thì hàm lượng nitơ axit amin và nitơ amoniac không khác biệt, nhưng hàm lượng peptide đạt cao nhất $(26,4 \mathrm{~g} / \mathrm{L})$.

Ở tỷ lệ enzyme thấp, thời gian thủy phân phải đảm bảo để enzyme có thể phân cắt các liên kêt trong cơ chất, tạo được sản phẩm cuối cùng mong muốn. Thời gian tác động kéo dài thì enzyme có điều kiện thủy phân protein triệt để, do đó hàm lượng peptide tăng khi kéo dài thời gian thủy phân (Do \& Nguyen, 2017). Ở cùng thời gian thủy phân, khi tăng tỷ lệ hỗn hợp enzyme từ 0,2 lên $0,3 \%$ thì hàm lượng peptide không khác biệt, hàm lượng nitơ axit amin giảm và nitơ amoniac tăng. Đồng thời, khi kéo dài thời gian ở tỷ lệ hỗn hợp enzyme $0,3 \%$ thì hàm lượng peptide và nitơ axit amin không khác biệt, nitơ amoniac tăng. Ở tỷ lệ enzyme cao, kéo dài thời gian thủy phân quá mức sẽ tạo điều kiện cho vi sinh vật gây thối hoạt động làm sản sinh ra nhiều sản phẩm cấp thấp như: $\mathrm{NH}_{3}, \mathrm{H}_{2} \mathrm{~S}$, indol, scaptol làm tăng hàm lượng nitơ amoniac (Do \& Nguyen, 2017). Trong khi đó, khi tăng thời gian thủy phân và tỷ lệ hỗn hợp enzyme lên $0,4 \%$ thì hàm lượng peptide giảm, nitơ amoniac giảm, nitơ axit amin tăng. Khi tỷ lệ hỗn hợp enzyme cao quá trình cắt mạch polypeptide (thủy phân protein), cũng như các sản phẩm của quá trình thủy phân xảy ra mãnh liệt đến sản phẩm cuối cùng là axit amin, dẫn đến giảm hàm lượng peptide và tăng hàm lượng nitơ axit amin (Tran \& Do, 2016).

Nghiệm thức (tỷ lệ hỗn hợp enzyme so với thịt cá và thời gian thủy phân là $0,2 \%$ : 26 giờ) cho hàm lượng peptide $(26,4 \mathrm{~g} / \mathrm{L})$ và nitơ axit amin $(10,6 \mathrm{~g} / \mathrm{L})$ cao nhất và hàm lượng nitơ amoniac thấp nhất là $0,257 \mathrm{~g} / \mathrm{L}$, nên là nghiệm thức thích hợp nhất được chọn để tiến hành thí nghiệm tiếp theo. 
Bảng 1. Thành phần hóa học của thịt cá lóc

\begin{tabular}{ccccc}
\hline Chỉ tiêu & Độ ẩm & Khoáng & Protein & Lipid \\
\hline Hàm lượng $(\%)^{1}$ & $79,8 \pm 0,53$ & $0,89 \pm 0,04$ & $16,9 \pm 0,50$ & $1,60 \pm 0,17$ \\
\hline${ }^{1}$ Số liệu được trình bày dưới dạng trung bình \pm độ lệch chuẩn, $\mathrm{n}=3$. &
\end{tabular}

Bảng 2. Hàm lượng peptide, nitơ axit amin và nitơ amoniac của dịch đạm

\begin{tabular}{cccc}
\hline $\begin{array}{c}\text { Tỷ lệ hỗn hợp } \\
\text { enzyme: Thời gian }\end{array}$ & $\begin{array}{c}\text { Hàm lượng peptide } \\
(\mathrm{g} / \mathrm{L})\end{array}$ & $\begin{array}{c}\text { Hàm lượng nitơ } \\
\operatorname{amoniac}(\mathrm{g} / \mathrm{L})\end{array}$ & $\begin{array}{c}\text { Hàm lượng nitơ } \\
\text { axit amin }(\mathrm{g} / \mathrm{L})\end{array}$ \\
\hline 0,2\%: 20 giờ & $25,4 \pm 0,60^{\mathrm{b}}$ & $0,258 \pm 0,039^{\mathrm{a}}$ & $11,4 \pm 0,53^{\mathrm{d}}$ \\
$0,3 \%: 20$ giờ & $25,7 \pm 0,34^{\mathrm{bc}}$ & $0,276 \pm 0,007^{\mathrm{b}}$ & $9,64 \pm 0,21^{\mathrm{ab}}$ \\
$0,4 \%: 20$ giờ & $21,7 \pm 0,88^{\mathrm{a}}$ & $0,254 \pm 0,010^{\mathrm{a}}$ & $9,32 \pm 0,53^{\mathrm{ab}}$ \\
$0,2 \%: 26$ giờ & $26,4 \pm 0,53^{\mathrm{c}}$ & $0,257 \pm 0,015^{\mathrm{a}}$ & $10,6 \pm 0,60^{\mathrm{cd}}$ \\
$0,3 \%: 26$ giờ & $26,1 \pm 0,29^{\mathrm{bc}}$ & $0,306 \pm 0,005^{\mathrm{c}}$ & $9,26 \pm 0,41^{\mathrm{a}}$ \\
$0,4 \%: 26$ giờ & $21,0 \pm 0,36^{\mathrm{a}}$ & $0,264 \pm 0,073^{\mathrm{a}}$ & $10,2 \pm 0,35^{\mathrm{bc}}$ \\
\hline$P_{\text {value }}$ & 0,000 & 0,000 & 0,002 \\
\hline
\end{tabular}

$\overline{\mathrm{a}-\mathrm{d}}$ Trong cùng một cột biểu thị sự khác biệt có ý nghĩa thống kê $(P<0,05)$, số liệu được biểu hiện dưới dạng trung bình \pm độ lệch chuẩn, $\mathrm{n}=3$.

\section{3. Ảnh hưởng của tỷ lệ dịch củ cải trắng: dịch đạm đến chất lượng sản phẩm}

Củ cải trắng chứa nhiều chất dinh dưỡng như protein, glucid, chất xơ, vitamin, khoáng chất... đóng vai trò quan trọng đối với sức khỏe con người, giúp tăng cường quá trình trao đổi chất, ngăn ngừa táo bón và bệnh tiểu đường ( $\mathrm{Lu} \&$ ctv., 2008). Vì vậy, bổ sung dịch củ cải nhằm tăng giá trị về mặt dinh dưỡng và cảm quan cho sản phẩm bột nêm. Kết quả độ ẩm, cảm quan, hiệu suất thu hồi và protein của sản phẩm bột nêm theo tỷ lệ dịch củ cải trắng : dịch đạm được thể hiện trong Bảng 3.

Từ Bảng 3 cho thấy, tỷ lệ dịch củ cải trắng tăng từ $25 \%$ đến $35 \%$ và tỷ lệ dịch đạm giảm từ $40 \%$ xuống $30 \%$ thì độ ẩm sản phẩm tăng từ $4,88 \%$ lên $6,05 \%$; hàm lượng protein và giá trị cảm quan giảm tương ứng từ (17,1\% và 18,9 điểm) xuống (14,5\% và 17,7 điểm); hiệu suất thu hồi không khác biệt. Độ ẩm tăng vì tỷ lệ dịch củ cải trắng tăng dần nên làm cho độ ẩm sản phẩm tăng theo. Protein giảm do tỷ lệ dịch đạm bổ sung vào giảm dần nên protein của sản phẩm cũng giảm theo. Khi bổ sung tỷ lệ dịch củ cải trắng: dịch đạm là 25\%:40\% thì đạt cảm quan tốt nhất (18,9 điểm), sản phẩm bột nêm có màu trắng ngà, có mùi đặc trưng của cá và gia vị, vị mặn ngọt hài hòa và trạng thái khô mịn, dạng bột rời không vón.

Độ ẩm của sản phẩm bột nêm trong nghiên cứu này cao hơn sản phẩm bột nêm thương mại là < $3 \%$ (được sấy bằng thiết bị sây phun). Vì trong nghiên cứu này, bột nêm được sấy bằng tủ sấy đối lưu tự nhiên ở $60^{\circ} \mathrm{C}$, để đạt độ ẩm sản phẩm $<3 \%$ thì thời gian sấy rất dài, do đó ảnh hưởng đến chất lượng cảm quan của sản phẩm. Vì vậy, sản phẩm được sấy ở $60^{\circ} \mathrm{C}$ trong 72 giờ để đạt giá trị cảm tốt nhất và độ ẩm thấp nhất.

Nghiệm thức với tỷ lệ dịch củ cải trắng: dịch đạm là 25\%:40\% cho điểm cảm quan bột nêm cao nhất 18,9 ; độ ẩm thấp nhất $(4,88 \%)$ và hàm lượng protein cao nhất $(17,1 \%)$, nên được chọn là thông số thích hợp nhất để tiến hành thí nghiệm tiếp theo.

\section{4. Ảnh hưởng của thời gian bảo quản đến chất lượng sản phẩm bột nêm}

Kết quả phân tích độ ẩm, cảm quan, tổng số vi khuẩn hiếu khí của sản phẩm bột nêm theo thời gian bảo quản ở nhiệt độ phòng được thể hiện ở Bảng 4.

Từ Bảng 4 cho thấy từ tuần 0 dến tuần 4 độ ẩm bột nêm tăng từ 4,88\% lên 8,09\%. Nguyên nhân có thể là do sự hút ẩm trong quá trình bảo quản. Sự hút ẩm phụ thuộc vào điều kiện bao gói, độ ẩm của không khí và đặc tính của sản phẩm (Nguyen \& Do, 1990). Bột nêm được cho vào túi $\mathrm{PA}$, do đó tùy thuộc vào tốc độ thấm khí của bao bì mà quá trình hút ẩm xảy ra nhiều hay ít (Dong, 2012). Đồng thời, sản phẩm được bảo quản ở nhiệt độ phòng nên có thể hút ẩm trở lại, đặc biệt là vào buổi tối khi độ ẩm không khí trong phòng có thể cao hơn độ ẩm của sản phẩm (Nguyen \& Do, 1990). Tổng số vi khuẩn hiếu khí tăng nhẹ từ $9,4 \times 10^{2} \mathrm{cfu} / \mathrm{g}$ lên $8,9 \times$ 
Bảng 3. Ảnh hưởng tỷ lệ dịch củ cải trắng : dịch đạm đến chất lượng của bột nêm

\begin{tabular}{ccccc}
\hline $\begin{array}{c}\text { Tỷ lệ dịch củ cải } \\
\text { trắng: dịch đạm }\end{array}$ & Độ ẩm $(\%)$ & $\begin{array}{c}\text { Hiệu suất thu } \\
\text { hồi }(\%)\end{array}$ & Protein $(\%)$ & $\begin{array}{c}\text { Điểm trung bình } \\
\text { có trọng lượng }\end{array}$ \\
\hline $20: 45$ & $5,23 \pm 0,35^{\mathrm{ab}}$ & $40,9 \pm 0,10^{\mathrm{a}}$ & $17,2 \pm 0,19^{\mathrm{c}}$ & $17,8 \pm 0,34^{\mathrm{a}}$ \\
$25: 40$ & $4,88 \pm 0,57^{\mathrm{a}}$ & $42,5 \pm 0,28^{\mathrm{a}}$ & $17,1 \pm 0,08^{\mathrm{c}}$ & $18,9 \pm 0,15^{\mathrm{b}}$ \\
$30: 35$ & $5,77 \pm 0,31^{\mathrm{bc}}$ & $41,9 \pm 0,73^{\mathrm{ab}}$ & $15,9 \pm 0,05^{\mathrm{b}}$ & $18,6 \pm 0,29^{\mathrm{b}}$ \\
$35: 30$ & $6,05 \pm 0,26^{\mathrm{c}}$ & $41,2 \pm 0,15^{\mathrm{a}}$ & $14,5 \pm 0,27^{\mathrm{a}}$ & $17,7 \pm 0,24^{\mathrm{a}}$ \\
\hline
\end{tabular}

a-c Trong cùng một cột biểu thị sự khác biệt có ý nghĩa thống kê $(P<0,05)$, số liệu được biểu hiện dưới dạng trung bình \pm độ lệch chuẩn, $\mathrm{n}=3$.

Bảng 4. Ảnh hưởng của thời gian bảo quản ở nhiệt độ phòng đến độ ẩm, cảm quan và tổng số vi khuẩn hiếu khí của sản phẩm bột nêm

\begin{tabular}{cccc}
\hline Thời gian (tuần) & Độ ẩm $(\%)$ & $\begin{array}{c}\text { Tổng số vi khuẩn } \\
\text { hiếu khí }(\mathrm{cfu} / \mathrm{g})\end{array}$ & $\begin{array}{c}\text { Điểm trung bình } \\
\text { có trọng lượng }\end{array}$ \\
\hline 0 & $4,88 \pm 0,57^{\mathrm{a}}$ & $9,4 \times 10^{2 \mathrm{a}}$ & $18,9 \pm 0,15^{\mathrm{c}}$ \\
1 & $5,24 \pm 0,40^{\mathrm{a}}$ & $3,0 \times 10^{3 \mathrm{ab}}$ & $18,8 \pm 0,03^{\mathrm{c}}$ \\
2 & $7,54 \pm 0,48^{\mathrm{b}}$ & $5,9 \times 103^{3 \mathrm{ab}}$ & $18,2 \pm 0,14^{\mathrm{b}}$ \\
3 & $7,97 \pm 0,23^{\mathrm{b}}$ & $7,0 \times 10^{3 \mathrm{ab}}$ & $17,9 \pm 0,34^{\mathrm{b}}$ \\
4 & $8,09 \pm 0,63^{\mathrm{b}}$ & $8,9 \times 10^{3 \mathrm{~b}}$ & $17,2 \pm 0,08^{\mathrm{a}}$ \\
\hline
\end{tabular}

${ }^{\mathrm{a}-\mathrm{c}}$ Trong cùng một cột biểu thị sự khác biệt có ý nghĩa thống kê $(P<0,05)$, số liệu được biểu hiện dưới dạng trung bình \pm độ lệch chuẩn, $\mathrm{n}=3$.

$10^{3} \mathrm{cfu} / \mathrm{g}$. Do sản phẩm hút ẩm nhẹ tạo điều kiện cho vi sinh vật phát triển (Nguyen \& Do, 1990). Bên cạnh đó, thời gian bảo quản càng dài thì vi sinh vật hiếu khí sẽ thích nghi dần với điều kiện bảo quản và tiếp tục phát triển, vì vậy tổng số vi khuẩn hiếu khí tăng (Adams \& Moss, 2008). Tổng số vi khuẩn hiếu khí sau 4 tuần bảo quản là $8,9 \times$ $10^{3} \mathrm{cfu} / \mathrm{g}$, thấp hơn giá trị tối đa cho phép $\left(10^{4}\right.$ cfu/g) theo TCVN 7396 : 2004 (2004). Do điều kiện thí nghiệm nên chưa tìm được thời hạn sử dụng chính xác của sản phẩm. Sản phẩm hạt nêm Aji-ngon gói $170 \mathrm{~g}$ của Nhật Bản có thời hạn sử dụng 12 tháng. Thời hạn sử dụng của sản phẩm hạt nêm thương mại dài hơn nghiên cứu này có thể do nguồn nguyên liệu, thành phần và tính chất của sản phẩm, thành phần bổ sung, điều kiện chế biến, bao gói và bảo quản sản phẩm (Nguyen \& Do, 1990). Chất lượng cảm quan giảm nhẹ sau 4 tuần bảo quản sản phẩm nhưng vẫn đạt được loại khá (17,2 điểm) theo TCVN 3215-79 (1979).

Sản phẩm bột nêm thành phẩm được sản xuất từ dịch đạm thu được từ quá trình thủy phân thịt cá lóc có giá trị dinh dưỡng cao, thể hiện ở hàm lượng protein chiếm $17,1 \%$; lipid và độ ẩm thấp lần lượt là $1,61 \%$ và 4,88\%, khoáng chiếm $12,0 \%$; sản phẩm bột nêm có màu trắng ngà, mùi đặc trưng của cá và gia vị, vị mặn ngọt hài hòa và trạng thái khô mịn, dạng bột rời không vón cục với điểm cảm quan cao đạt 18,9. Chỉ tiêu vi sinh của sản phẩm bột nêm đạt tiêu chuẩn cho phép theo TCVN 7396 : 2004 (2004).

\section{Kết Luận}

Dịch đạm thu được từ thịt cá lóc được thủy phân ở nhiệt độ $55^{\circ} \mathrm{C}$ với tỷ lệ hỗn hợp enzyme Alcalase và Flavouzyme so với thịt cá là $0,2 \%$ trong 26 giờ. Phối trộn với tỷ lệ dịch củ cải trắng: dịch đạm là 25\%:40\% cho sản phẩm bột nêm có hàm lượng protein tương đối cao $(17,1 \%)$. Sản phẩm bột nêm từ cá lóc vẫn đảm bảo an toàn về chỉ tiêu vi sinh, cảm quan và độ ẩm tốt sau 4 tuần bảo quản ở nhiệt độ phòng.

\section{Tài Liệu Tham Khảo (References)}

Adams, M. R., \& Moss, M. O. (2008). Food and microbiology. University of Surrey, Guildford, United Kingdom.

Bui, D. P., Truong, T. T. M., \& Tran, H. T. T T. (2014). Investigation of types of products from snakehead fish and their production process in An Giang province. Can Tho University Journal of Science 1, 36-41.

Chiang, J. H., Loveday, S. M., Hardacre1, A. K., \& Parker, M. E. (2019). Effects of enzymatic hydrolysis treatments on the physicochemical properties of beef bone extract using endo- and exoproteases. International Journal of Food Science and Technology 54, 111-120.

Dong, D. T. A. (2012). Food packaging. Ho Chi Minh City, Vietnam: Ho Chi Minh National University Publishers. 
Do, T. T. T., \& Nguyen, T. A. (2017). Enzymatic hydrolysis of spine scad (Decapterus ruselli) using the combination of alcalase and flavourzyme to produce protein hydrolysate solution. Journal of Fisheries Science and Technology 3, 73-79.

Hultmann, L., Phu, T. M., Tobiassen, T., Aas-Hansen, Ø., \& Rustad, T. (2012). Effects of pre-slaughter stress on proteolytic enzyme activities and muscle quality of farmed Atlantic cod (Gadus morhua). Food chemistry 134(3), 1399-1408.

Kamnerdpetch, C., Weiss, M., Kasper, C., \& Scheper, T. (2007). An improvement of potato pulp protein hydrolyzation process by the combination of protease enzyme systems. Enzyme and Microbial Technology 40(4), 508-514.

Latimer, G. W. (2016). Official methods of analysis of AOAC international. Rockville, USA: AOAC International.

Le, X. S., Navy, H., \& Pomeroy, R. S. (2014). Value chain of snakehead fish in the lower Mekong basin of Cambodia and Vietnam. Aquaculture Economics and Management 18, 76-96.

Liaset, B., Nortvedt, R., Lied, E., \& Espe, M. (2002). Studies on the nitrogen recovery in enzymic hydrolysis of Atlantic salmon (Salmo salar, L.) frames by Protamex $^{\mathrm{TM}}$ protease. Process Biochemistry 37(11), 1263-1269.

Lowry, O. H., Rosebrough, N. J., Farr, A. L., \& Randall, R. J. (1951). Protein measurement with the Folin phenol reagent. Journal of Biological Chemistry 193, 265-275.

Lu, Z., Liu, L., Li, X., Gong, Y., Hou, X., Zhu, X., \& Wang, L. (2008). Analysis and evaluation of nutritional quality in Chinese radish (Raphanus sativus L.). Agricultural Sciences in China 7(7), 823-830.

Nguyen, H. T. M.., Sylla, K. S. B., Randriamahatody, Z., Donnay-Moreno, C., Moreau, J., Tran, L. T., \& Bergé, J. P. (2011). Enzymatic hydrolysis of yellowfin tuna (Thunnus albacares) by-products using Protamex protease. Food Technology and Biotechnology 49(1), 48-55.
Nguyen, T., C., \& Do, M. P. (1990). Aquatic product processing, episode 2. Ha Noi, Vietnam: Agricultural Publishing House.

Pham, P. T. D. (2013). Preparation of shirmp flavor powder from carotenoprotein extracted from white shirmp heads. Journal of Fisheries Science and Technology 3, 39-46.

TCVN 7396 : 2004 (2004). Spicing salt powder - Technical requirements. Ha Noi, Vietnam: Ministry of Science and Technology.

TCVN 3706 - 90 (1990). Aquatic products - Method for determination of nitrogen ammonia content. Ha Noi, Vietnam: Ministry of Science and Technology.

TCVN 3708 - 90 (1990). Aquatic products - Method for the determination of nitrogen amino acid content. Ha Noi, Vietnam: Ministry of Science and Technology.

TCVN 5165 : 1990 (1990). Foods - Method for enumeration of total aerobic bacteria. Ha Noi, Vietnam: Ministry of Science and Technology.

TCVN 3215-79 (1979). Food products sensorial analysis Method by frointingmark. Ha Noi, Vietnam: Ministry of Science and Technology.

Tran, A. K., Nguyen, T. H., Nguyen, V. K. H., Nguyen, L. T. H., \& Pham, C. K (2017). Study of hydrolysis conditions of salmon waste to collect antioxidant peptides. VNU Journal of Science: Natural Science and Technology 33(1S), 7-13.

Tran, T. T. B., \& Do, T. T. T. (2016). Enzymatic hydrolysis of herring fish (Sardinella gibbosa) using protamex enzyme to prepare soluble protein solution. Journal of Fisheries Science and Technology 2, 93-100. 